University of Nebraska - Lincoln

DigitalCommons@University of Nebraska - Lincoln

Nebraska Game and Parks Commission -- Staff

Research Publications

Nebraska Game and Parks Commission

January 1976

THE EFFECTS OF BOATING UPON LEAD CONCENTRATIONS IN

$\mathrm{FISH}$

David Oates

Wildlife Research, Nebraska Game and Parks Commission, Lincoln, Nebraska

Follow this and additional works at: https://digitalcommons.unl.edu/nebgamestaff

Part of the Environmental Sciences Commons

Oates, David, "THE EFFECTS OF BOATING UPON LEAD CONCENTRATIONS IN FISH" (1976). Nebraska Game and Parks Commission -- Staff Research Publications. 13.

https://digitalcommons.unl.edu/nebgamestaff/13

This Article is brought to you for free and open access by the Nebraska Game and Parks Commission at DigitalCommons@University of Nebraska - Lincoln. It has been accepted for inclusion in Nebraska Game and Parks Commission -- Staff Research Publications by an authorized administrator of DigitalCommons@University of Nebraska - Lincoln. 


\title{
THE EFFECTS OF BOATING UPON LEAD CONCENTRATIONS IN FISH
}

\author{
David Oates \\ Wildlife Research, Nebraska Game and Parks Commission, \\ Lincoln, Nebraska 68503
}

\begin{abstract}
The concentration of lead in fish muscle tissue from lakes where boating is heavy and where it is prohibited was measured. The lead levels ranged from less than 0.05 to $1.35 \mathrm{ppm}$ but did not differ significantly between those in the controlled and noncontrolled boating lakes. Lead levels apparently pose no public health hazard. Trans. Kans. Acad. Sci., Vol. 79 (3-4), 1976.
\end{abstract}

In recent years, studies have revealed that lead concentrations are increasing in our environment. This increase can be attributed to the combustion of leaded gasoline (Page and Panje, 1970). Investigators have demonstrated significant correlations between motor vehicle traffic density and the amount of lead associated with soils (Page and Panje, 1970; Satterlee et al., 1975) and plants (Schuck and Locke, 1970; Lagerwerff and Specht, 1970). It was hypothesized that heavy motor boating traffic might contribute significantly to lead concentrations in the aquatic environment.

Lead in the aquatic environment from exhaust wastes is most likely to occur in relatively insoluble forms as in soil (Daines et al., 1970). Sedimental lead may be assimulated by plants and certain invertebrates. If biomagnification does occur, fish tissues would be expected to contain lead. Lead is known to be toxic, cumulative and deposited in bone tissue (Bowen, 1966).

Immediate concern was over excessive amounts of lead occuring in edible portions of fish. English et al. (1963a and 1963b) and Surber (1971) examined the tainting of the taste of fish due to outboard motor exhaust wastes. Lead in fish tissue was not determined at that time, but palatability was deleteriously affected. Several lakes in the eastern part of Nebraska are subject to heavy recreational use by both fishermen and water skiers. A study to determine lead levels in tissues of selected species of fish was therefore initiated. The purpose was to determine if fish from lakes receiving heavy motor boating pressure might constitute a health hazard.

Fish samples were taken from three lakes which received considerable boating pressure (Connestoga and Pawnee near Lincoln and Victory Lake at Fremont State Recreational Area). Two control lakes were chosen from the same areas: Yankee Hill near Lincoln and Lake \#2 at Fremont. Victory Lake and Fremont Lake \#2 are sandpit type lakes; 
Table I. Mean total length and weight of fishes collected for lead analysis.

\begin{tabular}{|c|c|c|c|c|}
\hline COLLECTION SITE & SPECIES & $\mathrm{N}$ & $\begin{array}{l}\text { MEAN TOTAL } \\
\text { LENGTH }(\mathrm{mm})\end{array}$ & $\begin{array}{l}\text { MEAN } \\
\text { WEIGHT (gm) }\end{array}$ \\
\hline \multirow[t]{3}{*}{ Victory Lake } & Largemouth Bass & 10 & 247.1 & 234.2 \\
\hline & Bluegill & 10 & 157.3 & 79.3 \\
\hline & Black Crappie & 10 & 171.6 & 53.0 \\
\hline Fremont Lake \#2 & Largemouth Bass & 9 & 244.3 & 300.1 \\
\hline \multirow[t]{2}{*}{ Pawnee Lake } & Biack Crappie & 10 & 212.1 & 144.8 \\
\hline & Bluegill & 10 & 159.9 & 77.3 \\
\hline \multirow[t]{2}{*}{ Connestoga Lake } & Black Crappie & 9 & 184.4 & 64.7 \\
\hline & Bluegill & 10 & 152.7 & 62.2 \\
\hline \multirow[t]{2}{*}{ Yankee Hill Lake } & Black Crappie & 10 & 206.0 & 130.9 \\
\hline & Bluegill & 10 & 162.2 & 84.0 \\
\hline
\end{tabular}

Connestoga, Pawnee and Yankee Hill lakes are surface water impoundments. Species collected and analyzed included largemouth bass (Micropterus salmoides), bluegill (Lepomis macrochirus) and black crappie (Pomoxis nigromaculatus) (Table 1).

All samples were homogenized boneless fillets which were stored at $-20^{\circ} \mathrm{C}$ in glass containers untit analysis. Lead was analyzed via Pekin-

Table II. Average concentrations of lead in fish muscle by individual species.

\begin{tabular}{|c|c|c|c|c|c|}
\hline AREA & SPECIES & & $N$ & $\begin{array}{l}\text { MEAN } \\
(\mathrm{ppm})\end{array}$ & $\begin{array}{l}\text { STANDARD } \\
\text { DEVIATION }\end{array}$ \\
\hline \multirow[t]{3}{*}{ Victory Lake } & Bluegill & (a) & 10 & 0.18 & 0.150 \\
\hline & Crappie & (a) & 10 & 0.32 & 0.443 \\
\hline & Largemouth bass & (a) & 10 & 0.31 & 0.093 \\
\hline Fremont Lake \#2 & Largemouth bass & (b) & 9 & 0.41 & 0.239 \\
\hline \multirow[t]{2}{*}{ Conestoga Lake } & Bluegill & (a) & 10 & 0.28 & 0.158 \\
\hline & Crappie & (a) & 9 & 0.77 & 0.259 \\
\hline \multirow[t]{2}{*}{ Pawnee Lake } & Bluegill & (a) & 10 & 0.33 & 0.186 \\
\hline & Crappie & (a) & 10 & 0.28 & 0.335 \\
\hline \multirow[t]{2}{*}{ Yankee Lake } & Blugill & (b) & 10 & 0.45 & 0.366 \\
\hline & Crappie & (b) & 10 & 0.22 & 0.182 \\
\hline
\end{tabular}

(a) Lakes with power boating

(b) Lakes without power boating 
Elmer methodology using an organic extraction technique devised by Yeager et al. (1971) Results are reported in parts per million on a wet weight basis (Table II).

The highest mean concentrations of lead $(0.51 \mathrm{ppm})$ were found in fish from Connestoga Lake (heavy motor boating); and the lowest mean concentrations $(0.27 \mathrm{ppm})$ from Victory Lake (heavy motor boating). The highest mean concentration of lead in an individual species was found in crappie $(0.77 \mathrm{ppm})$ from Connestoga Lake. The lowest mean was for Victory Lake bluegill $(0.18 \mathrm{ppm})$. Statistical analysis of lead concentrations in crappie from surface water impoundments indicated that these concentrations were significantly higher in fish from the two lakes where motor boating was heavy, (Table III). A similar test for lead concentra-

TABLE III. Comparison of mean lead concentrations in black crappie from surface water impoundments.

T TEST

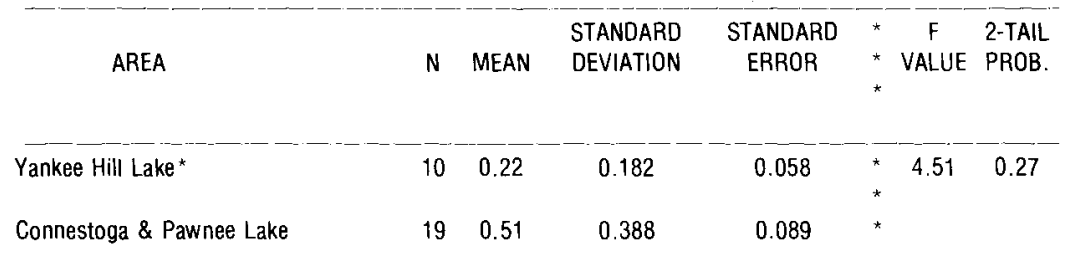

*No power boating

tions in bluegill found the reverse to be true. The mean lead concentration was significantly higher in fish from the non-motor boating lake, (Table IV). In the sandpit type lakes the mean concentration of lead in largemouth bass was also higher $(0.41$ to $0.31 \mathrm{ppm})$ in the non-boating lake than in the lake where motor boating was permitted. A one-way

Table IV. Comparison of mean lead concentrations in bluegill from surface water impoundments.

\section{T TEST}

\begin{tabular}{lccccccc}
\multicolumn{1}{c}{ AREA } & N MEAN & $\begin{array}{c}\text { STANDARD } \\
\text { DEVIATION }\end{array}$ & $\begin{array}{c}\text { STANDARD } \\
\text { ERROR }\end{array}$ & * & F & 2-TAIL \\
VALUE PROB.
\end{tabular}

*No power boating 
analysis of variance of all fish species combined indicated that there was no significant difference ( $95 \%$ level) in lead concentrations in fishes from these lakes (Table V). A Duncan's multiple range test on the combined fish species showed overlap in lead concentrations for the controlled and non-controlled motor boating lakes (Table VI).

Table $V$. One-way analysis of variance of lead concentations in fish muscle from several Nebraska lakes.

\begin{tabular}{lrcccr}
\hline \multicolumn{1}{c}{ SOURCE } & D.F. & SUM OF SQUARES & MEAN SQUARES & F RATIO & F PROB. \\
\hline Between groups & 4 & 0.7587 & 0.1897 & 2.300 & 0.064 \\
Within groups & 93 & 7.6711 & 0.0825 & & \\
\hline
\end{tabular}

Table VI. Duncan's multiple range test $(95 \%$ confidence level) of lead concentrations in fish muscle.

\begin{tabular}{|c|c|c|c|c|c|c|}
\hline \multirow[b]{2}{*}{ AREA } & \multirow[b]{2}{*}{$\mathrm{N}$} & \multirow[b]{2}{*}{$\begin{array}{l}\text { MEAN } \\
(\mathrm{ppm})\end{array}$} & \multirow[b]{2}{*}{$\begin{array}{l}\text { DUNCAN MULTIPLE } \\
\text { RANGE TEST }\end{array}$} & \multirow[b]{2}{*}{$\begin{array}{l}\text { STANDARD } \\
\text { ERROR }\end{array}$} & \multicolumn{2}{|c|}{-Range-- } \\
\hline & & & & & $\begin{array}{l}\text { MINIMUM } \\
\text { (ppm) }\end{array}$ & $\begin{array}{l}\text { MAXIMUM } \\
\text { (ppm) }\end{array}$ \\
\hline Victory Lake & 30 & 0.27 & & 0.0499 & $\bigcirc 0.05$ & 1.35 \\
\hline Pawnee Lake & 20 & 0.30 & & 0.0593 & 0.08 & 1.22 \\
\hline Yankee Hill Lake & 20 & 0.33 & & 0.0685 & $\therefore 0.05$ & 1.22 \\
\hline Fremont Lake \#2 & 9 & 0.41 & & 0.0795 & 0.20 & 1.00 \\
\hline Connestoga Lake & 19 & 0.51 & $\perp$ & 0.0752 & 0.07 & 1.08 \\
\hline
\end{tabular}

Analysis of whole fish or skeletal tissue might have shown a more significant difference in the lead concentrations for undetected bones can lead to incorrect and elevated values for some filleted samples.

The Food and Drug Administration has established a tolerance level for lead in evaporated milk of $0.3 \mathrm{ppm}$ to protect infants that may acquire more than half their average daily diet through dairy products (Federal Register, 1974). A tolerance has not been set for other foods. The Canadian Food and Drug Directorate has set a tolerance of $10.0 \mathrm{ppm}$ for lead. All samples were well below a $10 \mathrm{ppm}$ tolerance level. In order to give some perspective to our values, Kleinert et al. (1974) found lead concentrations ranging from 0.0 to $4.31 \mathrm{ppm}$ in twenty-six species of fish from Wisconsin. Morris et al. (1972) found values ranging from less than 0.01 to $.45 \mathrm{ppm}$ in lowa catfish. Dalton et al. (1969) found $0.88,6.93$ and 3.30 
ppm of lead in pork, beef and turkey tissue respectively. Our values ranging from less than 0.05 to 1.35 appear to indicate no public health hazard.

\section{ACKNOWLEDGEMENTS}

This study was supported by funds supplied by the Federal Aid Fish Restoration Act, under Dingell-Johnson Project F-4-R and the Nebraska Game and Parks Commission. The use of Nebraska Wesleyan University's atomic absorption spectrophotometer was greatly appreciated.

\section{REFERENCES}

Bowen, H. J. M., 1966. Trace elements in biochemistry. Academic Press, New York, New York, $241 \mathrm{pp}$.

Daines, R. H., H. Motto and D. M. Chilko, 1970. Atmospheric lead: its relationship to traffic volume and proximity to highways. Environmental Science and Technology. $4(4): 318$.

Dalton, E. F. and A. J. Malanoski, 1969. Atomic absorption analysis of copper and lead in meat and meat products. J. of A.O.A.C. 52 (5): 1035.

English, J. N., G. N. McDermott and D. Henderson, 1963a. Pollutional effects of outboard motor exhausts-laboratory studies. J. Water Pollution Control Fed. 35 (7): 923.

English, J. N., E. W. Surber and G. N. McDermott, 1963b. Pollutional effects of outboard motor exhausts-field study. J. Water Pollution Control Fed. 35 (9): 1121

Federal Register, 1974. Lead in evaporated milk and evaporated skim milk. 39 (236): 42740 .

Kleinert, S. J., P. E. Degurse and J. Ruhland, 1974. Surveys of toxic metals in Wisconsin (Concentration of metals in fish). Department of Natural Resources Tech. Bull. \#74.

Lagerwerff, J. V., and H. W. Specht, 1970. Contamination of roadside soil and vegetation with cadmium, nickel, lead and zinc. Environmental Science and Technology. $4(7): 583$.

Morris, R. L., L. G. Johnson and D. W. Ebert, 1972. Pesticides and heavy metals in the aquatic environment. Health Lab. 9 (2): 145

Page, A. L. and T. J. Panje, 1970. Accumulations of lead in soils for regions of high and low motor vehicle traffic density. Environmental Science and Technology, 4 (2): 140.

Satterlee, L., N. Y. Zachariah and R. M. Hill, 1975. Is car exhaust poisoning our corn? Farm Ranch and Home Quarterly. 22 (1): 11.

Schuck, E. H. and J. K. Locke, 1970. Relationship of automotive lead particulates to certain consumer crops. Environmental Science and Technology. 4 (4): 324 .

Surber, E. W., 1971. The effect of outboard motor exhaust wastes on fish and their environment. J. Wash. Acad. Sci. 61 (2): 120.

Yeager, D. W., J. Cholak and E. W. Henderson, 1971. Determination of lead in biological and related material by atomic absorption spectrophotometry. Environmental. Science and Technology 5 (10): 1020. 